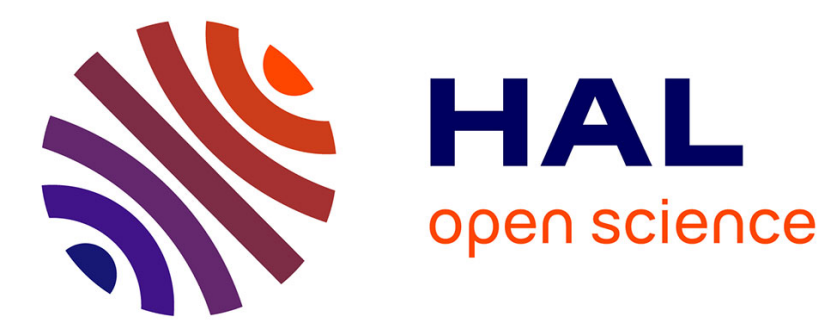

\title{
Orbital control on exceptional fossil preservation
}

Farid Saleh, Bernard Pittet, Jean-Philippe Perrillat, Bertrand Lefebvre

\section{To cite this version:}

Farid Saleh, Bernard Pittet, Jean-Philippe Perrillat, Bertrand Lefebvre. Orbital control on exceptional fossil preservation. Geology, 2019, 47, pp.103 - 106. 10.1130/g45598.1 . hal-03005022

\section{HAL Id: hal-03005022 \\ https://hal.science/hal-03005022}

Submitted on 13 Nov 2020

HAL is a multi-disciplinary open access archive for the deposit and dissemination of scientific research documents, whether they are published or not. The documents may come from teaching and research institutions in France or abroad, or from public or private research centers.
L'archive ouverte pluridisciplinaire HAL, est destinée au dépôt et à la diffusion de documents scientifiques de niveau recherche, publiés ou non, émanant des établissements d'enseignement et de recherche français ou étrangers, des laboratoires publics ou privés. 
Publisher: GSA

Journal: GEOL: Geology

DOI:10.1130/G45598.1

\section{Orbital control on exceptional fossil preservation}

2 Farid Saleh*, Bernard Pittet*, Jean-Philippe Perrillat*, and Bertrand Lefebvre*

3 Univ. Lyon, Université Claude Bernard Lyon 1, ENS de Lyon, CNRS, UMR 5276

4 Laboratoire de Géologie de Lyon: Terre, Planètes, Environnement, F-69622

5 Villeurbanne, France

6 *E-mails: farid.saleh@univ-lyon1.fr; bernard.pittet@univ-lyon1.fr; jean-

7 philippe.perrillat@univ-lyon1.fr; bertrand.lefebvre@univ-lyon1.fr

8 ABSTRACT

9 Exceptional preservation is defined by the preservation of soft to lightly

10 sclerotized organic tissues. The two most abundant types of soft tissues preservation are

11 carbonaceous compressions and replicates in authigenic minerals. In the geological

12 record, exceptionally preserved soft fossils are rare and generally limited to only a few

13 stratigraphic intervals. In the Fezouata Shale (Lower Ordovician), we found that deposits

14 yielding pyritized soft tissues contain iron-rich silicate minerals. These minerals played a

15 crucial role in inhibiting decaying bacteria and are comparable to those found in

16 formations yielding carbonaceous soft parts around the world. Furthermore, we found

17 that iron-rich minerals show a cyclic pattern of occurrence (of $\sim 100$ kyrs periodicity)

18 implicating a short eccentricity control through the general oceanic and atmospheric

19 circulations on iron availability. Our results identify, for the first time, an external climate

20 forcing on exceptional preservation and show that orbital forcing may be a level-selective

21 parameter responsible for the discontinuous occurrence of horizons preserving soft parts

22 around the world.

\section{INTRODUCTION}


Publisher: GSA

Journal: GEOL: Geology

DOI:10.1130/G45598.1

Exceptional preservation consists of the preservation of soft to lightly sclerotized

25 organic tissues (e.g., feathers, guts, skins) in the geological record (Butterfield, 1995).

26 The transfer of such tissues from the biosphere to the lithosphere is the result of a

27 succession of multiple, complex biological and geological mechanisms. Deciphering

28 these mechanisms is essential to understanding why exceptional preservation is limited to

29 specific intervals in the sedimentary record. Recent studies have shown that the

30 absence/presence of carbonaceous soft tissues is strongly correlated with the mineralogy

31 of the depositional environment and most importantly with iron-rich minerals that can

32 inhibit bacterial decay of soft tissues through the oxidative damage of bacterial cells

33 (McMahon et al., 2016; Anderson et al., 2018). However, little attention has been paid so

34 far to discover within which sediment minerals the pyritized soft tissues occur and what

35 are the processes behind the deposition of these minerals.

36 The Fezouata Shale crops out in the Zagora region in southern Morocco. This

37 Lower Ordovician succession consists of blue-green to yellow-green sandy mudstones

38 and siltstones that coarsen upwards. These sediments are up to $900 \mathrm{~m}$ thick in the Zagora

39 region (Destombes et al., 1985; Martin et al., 2016; Vaucher et al., 2017). The entire

40 succession was deposited in a marginal basin at high latitude close to the paleo-South

41 pole (Torsvik and Cocks, 2011, 2013). The shallow depositional setting ranges from the

42 foreshore to the upper offshore. It was storm-wave dominated (Martin et al., 2016) and

43 indirectly influenced by tides (Vaucher et al., 2017). The Fezouata Shale has yielded

44 abundant remains of soft-bodied organisms preserved with high fidelity, showing the

45 association of post-Cambrian taxa typical of the Great Ordovician Biodiversification

46 Event along with iconic taxa of the Cambrian Explosion (Van Roy et al., 2010, 2015). 
Publisher: GSA

Journal: GEOL: Geology

DOI:10.1130/G45598.1

47 Most soft bodied organisms were pyritized and are now preserved in iron oxides.

48 However, this weathering impact is not substantial as numerous fossils still show original

49 framboidal pyrite crystals. The presence of levels yielding both mineralized and soft

50 bodied organisms, as well as the highly constrained stratigraphic framework of this

51 formation (Gutiérrez-Marco and Martin, 2016; Lehnert et al., 2016; Martin et al., 2016;

52 Nowak et al., 2016; Lefebvre et al., 2018), make the Fezouata Shale a good candidate to

53 investigate whether specific sediment minerals are correlated with pyritized soft parts,

54 and if these mineralogical signatures change through time.

\section{MATERIAL AND METHODS}

\section{Mineralogical Signatures}

57 Part of the sedimentary succession of the Fezouata Shale (Vaucher et al. 2016)

58 was included in this study. The mineralogy of all fossiliferous levels in this section was

59 investigated. Mineral assemblages of levels yielding exceptional preservation were

60 compared to those in levels bearing only sclerotized remains. Matrix samples from each

61 level were prepared as randomly orientated powdered aggregates $(<10 \mu \mathrm{m})$, without any

62 specific treatments, on thermoplastic polymer (PMMA) substrates. X-ray diffraction

63 (XRD) was performed using a Bruker D8 Advance diffractometer, employing a $\mathrm{CuK} \alpha$

64 source and Bruker LynxeyeX detector. Peak positions were adjusted for slight variations

65 in sample height displacement error using positions of quartz peaks as internal standards.

66 Mineral phases were then retrieved based on indexation of their diffraction lines, between

670 and $75^{\circ} 2 \theta$ values, from the ICDD (International Centre for Diffraction Data) PDF4+

682016 reference database. Illite is generally characterized by its basal (001) peak at $\sim 10 \AA$.

69 Quartz is characterized by its intense (011) reflection at $3.34 \AA$. The differentiation 
Publisher: GSA

Journal: GEOL: Geology

DOI:10.1130/G45598.1

70 between chlorite minerals is verified based on the lateral variations of their characteristic

71 (001) and (002) peaks, respectively at 14 and $7 \AA$, as iron enrichment causes an increase

72 in d-spacing that shifts peaks positions toward higher $2 \theta$ values (Fig. 1). Phase

73 proportions were estimated from the relative intensity of diffraction lines of each mineral

74 species.

\section{Sequence Reconstructions}

76 The depositional environment of the Fezouata Shale is storm/wave dominated and

77 indirectly influenced by tides (Martin et al. 2016; Vaucher et al., 2016, 2017). In the

78 Fezouata Shale, the interaction of oscillations with surface sediments generated

79 oscillatory structures. The wavelength of these structures decreased from shallow to deep

80 environments (Nichols, 2010; Vaucher et al. 2016). Additionally, coarser sediments

81 indicate a shallower environment, while finer sediments are deposited in deeper settings

82 (Vaucher et al., 2016, 2017). These sediments and structural heterogeneities permitted the 83 establishment of a model of facies for the Fezouata Shale (Vaucher et al. 2017). Based on

84 this model, the alternation of deeper and shallower facies F1, F2 and F4 of Vaucher et al.

85 (2017) allowed us to identify small-, medium- and large-scale sequences. Small-scale

86 sequences correspond to the shortest variations of the sea level (Fig. 2), whereas medium-

87 and large-scale sequences correspond to longer terms sea-level changes.

\section{Bathymetry and Oxygenation}

89 The depth of the water column was estimated accordingly with medium-scale sea

90 level sequences (Lefebvre et al., 2016; Vaucher et al., 2017). Relative oxygen

91 abundances in superficial sediments was reconstructed based on depth variations of the

92 water column. In the Fezouata environment, in deep environments, in shelf settings 
Publisher: GSA

Journal: GEOL: Geology

DOI:10.1130/G45598.1

93 below storm wave base, rapid burial did not occur, inhibiting the establishment of anoxic

94 conditions in surface sediments (Vaucher et al., 2017). Above storm wave base, where

95 rapid burial during storm events occurred, the establishment of anoxic conditions in

96 surface sediments below the storm deposits was influenced by wave/sediment

97 interactions. Wave/sediment interactions are more pronounced in shallow-most settings

98 (Nichols, 2010), leading to an increase in the oxygen penetration depth from the water

99 column to the sediments (Chatelain and Guizien, 2010). Thus, anoxic/dysoxic conditions

100 occur rarely in the shallowest environments (decimetric wavelength of storm oscillatory

101 structures, high oxygen penetration depth) and may occur only in less shallow deposits

102 (centimetric wavelength of storm structures, limited oxygen penetration depth) just above

103 the storm wave base (Fig. 2) in the Fezouata Shale (Vaucher et al. 2016., 2017).

\section{RESULTS}

105 All samples show a similar composition with an absence of organic matter, a high

106 abundance of illite $\left(\mathrm{K}, \mathrm{H}_{3} \mathrm{O}\right)(\mathrm{Al}, \mathrm{Mg}, \mathrm{Fe})_{2}(\mathrm{Si}, \mathrm{Al})_{4} \mathrm{O}_{10}\left[(\mathrm{OH})_{2},\left(\mathrm{H}_{2} \mathrm{O}\right)\right](\sim 60 \%)$ and quartz

$107 \mathrm{SiO}_{2}(\sim 30 \%)$, and a small portion $(<10 \%)$ of chlorite minerals (see Table DR1 in the Data

108 Repository for precise percentages). However, the nature of the chlorite phase differs

109 between samples as some specimens show the presence of clinochlore

$110\left(\mathrm{Mg}_{5} \mathrm{Al}\right)\left(\mathrm{AlSi}_{3}\right) \mathrm{O}_{10}(\mathrm{OH})_{8}$, while others show iron-rich clinochlore

$111(\mathrm{Mg}, \mathrm{Fe})_{5} \mathrm{Al}\left(\mathrm{Si}_{3} \mathrm{Al}\right) \mathrm{O}_{10}(\mathrm{OH})_{8}$ (iron content $\left.\sim 12 \%\right)$ or chamosite $\left(\mathrm{Fe}_{5} \mathrm{Al}\right)\left(\mathrm{AlSi}_{3}\right) \mathrm{O}_{10}(\mathrm{OH})_{8}$

112 (iron content $\sim 30 \%$ ) (Fig. 2). In the Fezouata Shale, the occurrence of soft tissues is

113 discontinuous and is limited only to few stratigraphic levels in interval 1 (Fig. 2). 
Publisher: GSA

Journal: GEOL: Geology

DOI:10.1130/G45598.1

114 The entire sedimentary succession was deposited around the storm wave base.

115 Both intervals 1 and 3 (Fig. 2), were deposited under anoxic/dysoxic conditions. The

116 largest part of interval 2 was deposited under oxic conditions (Fig. 2).

117 The studied section contains $\sim 2$ medium-scale and 9 small-scale sequences. The

118 occurrence of 4 small-scale sequences per medium-scale sequence deduced from facies

119 changes (Fig. 2) in the entire sedimentary succession suggests an eccentricity control on

120 sequence formation through its 100 and 400 kyrs periodicities. The studied sediments

121 were deposited during the Tremadocian (duration of $7.7 \pm 3.3 \mathrm{Ma}$ ). In the Tremadocian,

12210 main graptolites subdivisions (biozones) of $\sim 0,7 \mathrm{Ma}$ have been identified (Loydell,

123 2012). In the Fezouata Shale, the first three biozones of the Tremadocian are missing

124 (Gutiérrez-Marco and Martin, 2016; Lefebvre et al., 2018). This suggests that the

125 Tremadocian sediments $(450 \mathrm{~m})$ of the Fezouata Shale were deposited over $5.7 \pm 2.4 \mathrm{Ma}$.

126 In addition, the sedimentation of the Fezouata Shale appears to be uniform (i.e.,

127 monotonous sequence dominated by siltstones) and formed by the stacking of storm

128 deposits (mm- to cm-thick sandstone or coarse siltstone levels separated by mm-thick

129 argillaceous siltstone or fine-grained siltstone layers) (Vaucher et al., 2016, 2017). This

130 homogeneity of the sediments and the absence of observed long or short-term

131 sedimentary hiatus (Vaucher et al., 2017) both suggest a relatively stable accumulation

132 rate of $\sim 79 \mathrm{~m} / \mathrm{Ma}$. Thus, the studied $67 \mathrm{~m}$-thick section was deposited over $\sim 0.84 \pm 0.35$

133 Ma. One medium-scale sequence would then represent a time interval of $\sim 0.42 \pm 0.17$

$134 \mathrm{Ma}$, and one small-scale sequence of $0.09 \pm 0.03 \mathrm{Ma}$. These estimated durations are in

135 accordance with the durations of eccentricity cycles.

136 DISCUSSION

Page 6 of 15 
Publisher: GSA

Journal: GEOL: Geology

DOI:10.1130/G45598.1

The sediment in the Fezouata Shale has a relatively simple composition

138 comparable to other Paleozoic sites with exceptional preservation (Anderson et al., 2018).

139 In this formation, chamosite appears to be correlated with levels recording exceptional

140 preservation (Fig. 2). Chamosite can be formed directly from the transformation of

141 primary clay minerals (kaolinite, glauconite) at high temperatures $\left(\mathrm{T}>175^{\circ} \mathrm{C}\right)$ or from the

142 transformation of berthierine, an iron rich serpentine phyllosilicate, in less extreme

143 conditions $\left(\mathrm{T}<100^{\circ} \mathrm{C}\right.$; Tang et al., 2017). In the Fezouata Shale, sediments did not

144 endure extreme temperatures and burial conditions, and only $2-3 \mathrm{~km}$ (i.e., equivalent of

145 burial temperatures between 70 and $100{ }^{\circ} \mathrm{C}$ using a mean geothermal gradient of $30^{\circ}$ per

$146 \mathrm{~km}$ in passive margins) of sediments were deposited over these shales (Ruiz et al., 2008).

147 Thus, berthierine is the most probable precursor for chamosite in the Fezouata Shale. In

148 addition to that, chamosite occurrences appear to be correlated with an intermediate

149 bathymetry, as it occurs only in intervals 1 and 3 (Fig. 2). In the Fezouata Shale, specific

150 parameters (e.g. bathymetry, oxygenation) controlled the precipitation of berthierine in

151 the depositional environment and were thus indirectly responsible of the selective

152 presence of chamosite.

153 In a depositional environment, the presence of a significant amount of iron under

154 reducing conditions leads to the precipitation of berthierine (Tang et al., 2017), a mineral

155 which can inhibit decay bacteria (McMahon et al., 2016). Afterward, during a deeper

156 burial, most of the berthierine is transformed to chamosite (Hornibrook and Longstaffe,

157 1996). In some levels of intervals 1 and 3, reducing conditions and abundant iron were

158 available, leading to berthierine precipitation in sediments in addition to the pyritization

159 of decaying soft parts. In interval 1, some levels, deposited under similar bathymetry (i.e., 
Publisher: GSA

Journal: GEOL: Geology

DOI:10.1130/G45598.1

160 fast burial and sedimentary anoxia), yield mostly clinochlore instead of chamosite.

161 Clinochlore and chamosite belong to the same chlorite mineral group, and lie on its

162 magnesium-rich and iron-rich poles respectively (Curtis et al., 1985). The occurrence of

163 both chamosite and clinochlore in intervals with different porosities suggests that the

164 formation of these minerals is independent from the physical parameters in the sediments.

165 Instead, the presence of clinochlore is likely related to iron deficiencies in these levels

166 during early diagenesis.

167 In interval 2, chamosite is absent, and was mainly replaced by iron rich

168 clinochlore indicating the presence of iron. The absence of chamosite and exceptional

169 preservation in this interval were due to the absence of favorable reducing conditions

170 (Fig. 2).

171 Iron, an important element for the formation of both berthierine and pyrite, may

172 have different sources such as (i) circulation of iron-rich hydrothermal fluids (Tang et al.,

173 2017), (ii) microbial extraction of iron from clay minerals after their deposition in marine

174 sediments (Vorhies and Gaines, 2009) or (iii) iron inputs to the sea from other marine or

175 continental sources (Odin and Matter, 1981). In the Fezouata Shale, illite, which is the

176 main clay mineral in sedimentary basins (Ruiz et al. 2008), is present in all intervals.

177 However, chamosite does not occur in all levels showing a different distribution than

178 illite. This implies that the scenario considering microbial iron extraction from clay

179 minerals is not parsimonious. In addition, the occurrence of chamosite at the end of a

180 regression/ beginning of a transgression of a small-scale sequence (Fig. 2) rules out

181 hydrothermal fluids as the main source of iron and favors marine and/or continental

182 inputs. The Fezouata Shale was deposited in a shallow sea near the South Pole with a 
Publisher: GSA

Journal: GEOL: Geology

DOI:10.1130/G45598.1

183 limited oceanic circulation (Martin et al., 2016, Vaucher et al., 2017). Thus, the

184 enrichment of iron is considered as continental in origin.

185 According to duration estimations based on graptolite biostratigraphy, any two

186 consecutive iron rich intervals in interval 1 were deposited with an average delay of $\sim 100$

187 kyrs in pace with eccentricity-controlled sea-level cycles (Fig. 2). Astronomic

188 calculations confirmed that even if the periodicity of the obliquity and precession

189 decreased with time, eccentricity frequency was stable over the last 500 million years

190 (Berger et al., 1992). These calculations were validated through robust responses of

191 different sedimentary systems to astronomically controlled climate forcing from recent

192 times to the Cambrian (Osleger and Read, 1991). Every 100 kyrs, eccentricity transitions

193 from a circular to an elliptic orbit, or vice versa, influencing precession and thus,

194 insolation and seasonal variations (Fig. 3). Consequently, these variations influence the

195 evaporation/precipitation cycle, ice volume (Rampino, 1979), if any, as well as river

196 fluxes and continental weathering (Horton et al., 2012), and thus the inputs of iron to the

197 sea (Fig. 3). These inputs constitute a major contributor to iron abundances in oceans

198 (Elrod et al., 2004), and lead to berthierine formation in shallow environments at the

199 water/sediment interface (Odin and Gupta, 1988; Kozłowska and Maliszewska, 2015)

200 when anoxic conditions are present (Tang et al. 2010).

201 For the first time, our results (1) provide detailed information on the

202 mineralogical context in which pyritized soft tissues occur, (2) identify a temporal

203 variation of minerals in a sedimentary succession with soft tissue preservation, and (3)

204 evidence an orbital control on soft tissue fossilization. This external climate forcing may

205 be responsible for the discontinuous occurrence of soft tissues in numerous formations 
Publisher: GSA

Journal: GEOL: Geology

DOI:10.1130/G45598.1

206 around the world in which iron discrepancies between levels yielding exceptional

207 preservation and those with only skeletal remains are evidenced (Anderson et al., 2018).

208 ACKNOWLEDGMENTS

209 This paper is a contribution to the TelluS-INTERRVIE project 'Mécanismes de

210 préservation exceptionnelle dans la Formation des Fezouata', funded by the INSU,

211 CNRS. The authors thank Pierre Sansjofre and Muriel Vidal for assistance during field

212 work in Morocco, Guillaume Suan and Vincent Perrier for their advices, and Ruben Vera

213 for assistance in XRD preparation. Three reviewers are also thanked for their helpful and

214 constructive remarks.

215 REFERENCES CITED

216 Anderson, R.P., Tosca, N.J., Gaines, R.R., Mongiardino Koch, N., and Briggs, D.E., 217 2018, A mineralogical signature for Burgess Shale-type fossilization: Geology, $218 \quad$ v. 46, p. $347-350$, https://doi.org/10.1130/G39941.1.

219 Berger, A., Loutre, M.F., and Laskar, J., 1992, Stability of the astronomical frequencies

220 over the Earth's history for paleoclimate studies: Science, v. 255, p. 560-566,

$221 \quad$ https://doi.org/10.1126/science.255.5044.560.

222 Butterfield, N.J., 1995, Secular distribution of Burgess-Shale-type preservation: Lethaia,

223 v. 28 , p. 1-13, https://doi.org/10.1111/j.1502-3931.1995.tb01587.x.

224 Chatelain, M., and Guizien, K., 2010, Modelling coupled turbulence-dissolved oxygen

225 dynamics near the sediment-water interface under wind waves and sea swell: Water

226 Research, v. 44, p. 1361-1372, https://doi.org/10.1016/j.watres.2009.11.010.

227 Curtis, C.D., Hughes, C.R., Whiteman, J.A., and Whittle, C.K., 1985, Compositional

228 variation within some sedimentary chlorites and some comments on their origin: 
Publisher: GSA

Journal: GEOL: Geology

DOI:10.1130/G45598.1

Mineralogical Magazine, v. 49, p. 375-386,

https://doi.org/10.1180/minmag.1985.049.352.08.

231 Destombes, J., Hollard, H., and Willefert, S., 1985, Lower Palaeozoic rocks of Morocco,

232 in Holland, C.H., ed., Lower Palaeozoic Rocks of the World, volume 4: Lower

233 Palaeozoic rocks of Northwest and West-Central Africa: Chichester, UK, John Wiley

234 and Sons, p. 91-336.

235 Elrod, V.A., Berelson, W.M., Coale, K.H., and Johnson, K.S., 2004, The flux of iron

236 from continental shelf sediments: A missing source for global budgets: Geophysical

237 Research Letters, v. 31, L12307, https://doi.org/10.1029/2004GL020216.

238 Gutiérrez-Marco, J.C., and Martin, E.L.O., 2016, Biostratigraphy and palaeoecology of

239 Lower Ordovician graptolites from the Fezouata Shale (Moroccan Anti-Atlas):

240 Palaeogeography, Palaeoclimatology, Palaeoecology, v. 460, p. 35-49,

$241 \quad$ https://doi.org/10.1016/j.palaeo.2016.07.026.

242 Hornibrook, E.R.C., and Longstaffe, F.J., 1996, Berthierine from the Lower Cretaceous

243 Clearwater Formation, Alberta, Canada: Clays and Clay Minerals, v. 44, p. 1-21,

244 https://doi.org/10.1346/CCMN.1996.0440101.

245 Horton, D.E., Poulsen, C.J., Montañez, I.P., and DiMichele, W.A., 2012, Eccentricity-

246 paced late Paleozoic climate change: Palaeogeography, Palaeoclimatology,

247 Palaeoecology, v. 331-332, p. 150-161,

$248 \quad$ https://doi.org/10.1016/j.palaeo.2012.03.014.

249 Kozłowska, A., and Maliszewska, A., 2015, Berthierine in the Middle Jurassic sideritic

250 rocks from southern Poland: Geological Quarterly, v. 59, p. 551-564. 
Publisher: GSA

Journal: GEOL: Geology

DOI:10.1130/G45598.1

251 Lefebvre, B., et al., 2016, Palaeoecological aspects of the diversification of echinoderms

252 in the Lower Ordovician of central Anti-Atlas, Morocco: Palaeogeography,

253 Palaeoclimatology, Palaeoecology, v. 460, p. 97-121,

$254 \quad$ https://doi.org/10.1016/j.palaeo.2016.02.039.

255 Lefebvre, B., Gutiérrez-Marco, J.C., Lehnert, O., Martin, E.L.O., Nowak, H., Akodad,

256 M., El Hariri, K., and Servais, T., 2018, Age calibration of the Lower Ordovician

257 Fezouata Lagerstätte, Morocco: Lethaia, v. 51, p. 296-311,

$258 \quad$ https://doi.org/10.1111/let.12240.

259 Lehnert, O., Nowak, H., Sarmiento, G.N., Gutiérrez-Marco, J.C., Akodad, M., and

260 Servais, T., 2016, Conodonts from the Lower Ordovician of Morocco - contributions

261 to age and faunal diversity of the Fezouata Lagerstätte and peri-Gondwana

262 biogeography: Palaeogeography, Palaeoclimatology, Palaeoecology, v. 460, p. 50-

263 61, https://doi.org/10.1016/j.palaeo.2016.03.023.

264 Loydell, D.K., 2012, Graptolite biozone correlation charts: Geological Magazine, v. 149,

265 p. 124-132, https://doi.org/10.1017/S0016756811000513.

266 Martin, E.L.O., et al., 2016, The Lower Ordovician Fezouata Konservat-Lagerstätte from

267 Morocco: Age, environment and evolutionary perspectives: Gondwana Research,

268 v. 34 , p. 274-283, https://doi.org/10.1016/j.gr.2015.03.009.

269 McMahon, S., Anderson, R.P., Saupe, E.E., and Briggs, D.E., 2016, Experimental

270 evidence that clay inhibits bacterial decomposers: Implications for preservation of

271 organic fossils: Geology, v. 44, p. 867-870, https://doi.org/10.1130/G38454.1.

272 Nichols, G., 2010, Sedimentology and Stratigraphy: Chichester, UK, Wiley-Blackwell, $273432 \mathrm{p}$. 
Publisher: GSA

Journal: GEOL: Geology

DOI:10.1130/G45598.1

274 Nowak, H., Servais, T., Pittet, B., Vaucher, R., Akodad, M., Gaines, R.R., and

275 Vandenbroucke, T.R., 2016, Palynomorphs of the Fezouata Shale (Lower

276 Ordovician, Morocco): Age and environmental constraints of the Fezouata Biota:

277 Palaeogeography, Palaeoclimatology, Palaeoecology, v. 460, p. 62-74,

$278 \quad$ https://doi.org/10.1016/j.palaeo.2016.03.007.

279 Odin, G.S., and Gupta, B.K.S., 1988, Geological Significance of the Verdine Facies:

280 Developments in Sedimentology, v. 45, p. 205-219, https://doi.org/10.1016/S0070-

$281 \quad 4571(08) 70064-5$.

282 Odin, G.S., and Matter, A., 1981, De glauconiarum origine: Sedimentology, v. 28,

p. 611-641, https://doi.org/10.1111/j.1365-3091.1981.tb01925.x.

284 Osleger, D., and Read, J.F., 1991, Relation of eustasy to stacking patterns of meter-scale 285 carbonate cycles, Late Cambrian, USA: Journal of Sedimentary Research, v. 61, 286 p. 1225-1252.

287 Rampino, M.R., 1979, Possible relationships between changes in global ice volume, 288 geomagnetic excursions, and the eccentricity of the Earth's orbit: Geology, v. 7, p. 584-587, https://doi.org/10.1130/0091-7613(1979)7<584:PRBCIG>2.0.CO;2.

290 Ruiz, G., Helg, U., Negro, F., Adatte, T., and Burkhard, M., 2008, Illite crystallinity

291 patterns in the Anti-Atlas of Morocco: Swiss Journal of Geosciences, v. 101, p. 387$292 \quad 395$, https://doi.org/10.1007/s00015-008-1267-z.

293 Tang, D., Shi, X., Jiang, G., Zhou, X., and Shi, Q., 2017, Ferruginous seawater facilitates

294 the transformation of glauconite to chamosite: An example from the

295 Mesoproterozoic Xiamaling Formation of North China: American Mineralogist,

296 v. 102, p. 2317-2332, https://doi.org/10.2138/am-2017-6136. 
Publisher: GSA

Journal: GEOL: Geology

DOI:10.1130/G45598.1

297 Torsvik, T.H., and Cocks, L.R.M., 2011, The Palaeozoic palaeogeography of central

298 Gondwana: Geological Society of London, Special Publications, v. 357, p. 137-166,

299 https://doi.org/10.1144/SP357.8.

300 Torsvik, T.H., and Cocks, L.R.M., 2013, New global palaeogeographical reconstructions

301 for the Early Palaeozoic and their generation: Geological Society, London, Memoir

$302 \quad 38$, p. 5-24.

303 Van Roy, P., Orr, P.J., Botting, J.P., Muir, L.A., Vinther, J., Lefebvre, B., El Hariri, K.,

304 and Briggs, D.E., 2010, Ordovician faunas of Burgess Shale type: Nature, v. 465,

305 p. 215-218, https://doi.org/10.1038/nature09038.

306 Van Roy, P., Briggs, D.E.G., and Gaines, R.R., 2015, The Fezouata fossils of Morocco;

307 an extraordinary record of marine life in the Early Ordovician: Journal of the

308 Geological Society, v. 172, p. 541-549, https://doi.org/10.1144/jgs2015-017.

309 Vaucher, R., Martin, E.L.O., Hormière, H., and Pittet, B., 2016, A genetic link between

310 Konzentrat and Konservat Lagerstätten in the Fezouata Shale (Lower Ordovician,

311 Morocco): Palaeogeography, Palaeoclimatology, Palaeoecology, v. 460, p. 24-34,

312 https://doi.org/10.1016/j.palaeo.2016.05.020.

313 Vaucher, R., Pittet, B., Hormière, H., Martin, E.L.O., and Lefebvre, B., 2017, A wave-

314 dominated, tide-modulated model for the lower Ordovician of the anti-atlas,

315 Morocco: Sedimentology, v. 64, p. 777-807, https://doi.org/10.1111/sed.12327.

316 Vorhies, J.S., and Gaines, R.R., 2009, Microbial dissolution of clay minerals as a source

317 of iron and silica in marine sediments: Nature Geoscience, v. 2, p. 221-225,

318 https://doi.org/10.1038/ngeo441.

319

Page 14 of 15 
Publisher: GSA

Journal: GEOL: Geology

DOI:10.1130/G45598.1

\section{FIGURE CAPTIONS}

321

322 Figure 1. Minerals identification in samples from the Fezouata Shale from X-ray powder

323 diffraction. The box with red margins is an expansion of the area indicated in the main 324 plot.

326 Figure 2. From left to right: sequences of various scales translating sea-level cycles at

327 different timescales, part of the sedimentary succession of Fezouata Shale with location

328 of samples, facies F1, F2 and F4 as described in Vaucher et al. (2017) used to identify the

329 sequences, relative bathymetry changes and oxygen fluctuations.

330

331 Figure 3. Model explaining the effect of orbital forcing on seasonality, and thus on soft

332 tissues preservation.

333

334 1GSA Data Repository item 2018xxx, xxxxxxxxxxxxxxxx, is available online at

335 http://www.geosociety.org/datarepository/2018/, or on request from

336 editing@geosociety.org. 


\section{Large, medium and small scale sequences}

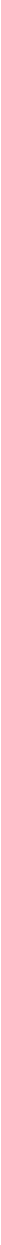

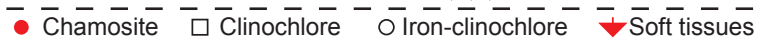



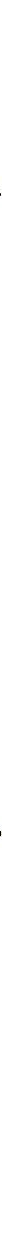